\title{
De laatste berg
}

Citation for published version (APA):

van Praag, H. M. (1993). De laatste berg. Bohn Stafleu van Loghum. https://doi.org/10.26481/spe.19930401hp

Document status and date:

Published: 01/04/1993

DOI:

10.26481/spe.19930401hp

Document Version:

Publisher's PDF, also known as Version of record

\section{Please check the document version of this publication:}

- A submitted manuscript is the version of the article upon submission and before peer-review. There can be important differences between the submitted version and the official published version of record.

People interested in the research are advised to contact the author for the final version of the publication, or visit the DOI to the publisher's website.

- The final author version and the galley proof are versions of the publication after peer review.

- The final published version features the final layout of the paper including the volume, issue and page numbers.

Link to publication

\footnotetext{
General rights rights.

- You may freely distribute the URL identifying the publication in the public portal. please follow below link for the End User Agreement:

www.umlib.nl/taverne-license

Take down policy

If you believe that this document breaches copyright please contact us at:

repository@maastrichtuniversity.nl

providing details and we will investigate your claim.
}

Copyright and moral rights for the publications made accessible in the public portal are retained by the authors and/or other copyright owners and it is a condition of accessing publications that users recognise and abide by the legal requirements associated with these

- Users may download and print one copy of any publication from the public portal for the purpose of private study or research.

- You may not further distribute the material or use it for any profit-making activity or commercial gain

If the publication is distributed under the terms of Article $25 \mathrm{fa}$ of the Dutch Copyright Act, indicated by the "Taverne" license above, 


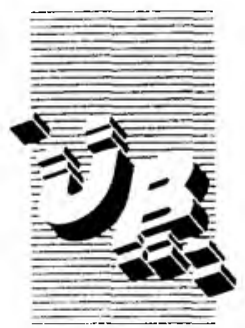

De uitleentermıjn verstrıjkt op:

\title{
2014 PD 1002
}

\section{MEI 1993}

\author{
14 OKT. 1993 \\ $1+.14 i .1908$ \\ 19 1004. 3935 \\ - 6 DEC. 1996
}

Postbus 616

6200 MD Maastricht

Gelieve deze publicatie tijdig te retourneren of (telefonisch) verlenging van de vitleentermijn aan te vragen. 
DE LAATSTE BERG 


\section{DE LAATSTE BERG}

Rede

Uitgesproken bij de aanvaarding van het ambt van gewoon hoogleraar in de psychiatrie aan de Rijksuniversiteit Limburg te Maastricht op donderdag I april 1993. 


$$
\begin{gathered}
p=1065171368 \\
\text { Bilbliotheek } \\
\text { R.U. Limburg }
\end{gathered}
$$

Abonn 
Het leven is van zichzelf smaak-loos, omdat het alleen maar is 'er zijn'. Derhalve wordt het bestaan voor de mens een dichterlijke arbeid, die van een toneel- of romanschrijver: voor zijn bestaan een inhoud te vinden, er een vorm aan te geven die het op een of andere manier suggestief en aanlokkelijk maakt.

José Ortega y Gasset, Zelfinkeer en Verbijstering, 1949 

In dankbaarheid en met eerbied opgedragen aan de nagedachtenis van mijn vader. 


\section{INHOUD}

I Het waarom $r$

2 Het credo II

2.I Onderzoek om als vak te overleven II

2.2 Het hersenen-en-gedrag mysterie $\quad$ I3

2.3 Klinisch-academische toenadering $\quad$ I6

2.4 Filosofische detente $\quad 20$

2.5 Blondering van het zwarte schaap 23

2.6 Onderwijs in de psychiatrie: op zoek naar een sokkel 25

3 De laatste berg 28

4 Dank 29

Literatuur 
Zeer gewaardeerde toehoorders,

\section{Het waarom}

Tot voor kort was ik hoofd van een bloeiende afdeling Psychiatrie van een gerenommeerde Medical School in de Verenigde Staten. Waarom moest die man dan zo nodig naar Maastricht komen? Die vraag is mij herhaaldelijk gesteld en is vermoedelijk nog vaker gedacht, maar verzwegen. Ik ben $U$ een antwoord schuldig, al was het alleen maar omdat mijn beweegredenen enig licht kunnen werpen op de man die heden voor $U$ staat. Een indruk te krijgen van de figuur die de Universiteit voor een bepaald vakgebied heeft binnengehaald is tenslotte de voornaamste reden voor een openbare les.

Welnu, het komt mij voor dat de voornaamste redenen voor mijn overstap gelegen zijn in mijn persoonlijkheidsstructuur, in combinatie met de levensfase waarin ik verkeer. Ik herken in mijzelf een zekere rusteloosheid, een onwil om me ergens permanent te vestigen, een drang om op pad te blijven. Mijn zelfbeeld is dat van een passant, van een doortrekker. Ik hecht me aan mensen, niet zozeer aan plaatsen. Ik kom, verricht een taak, en ga heen, op zoek naar nieuwe intellectuele avonturen. Ik ben een soort hybride van de Wandelende Jood en de Vliegende Hollander, overeenkomstig mijn dubbele wortels. Ik trek voort, niet gedreven door noodlot of toeval, maar doelgericht en uit vrije wil. Ik beschouw mijzelf dus als een opgewekte wandelaar en een tevreden vlieger. Op pad waarheen? Op pad naar, of beter: mijzelf opwerkende tot een gevoel van vrijheid en onafhankelijkheid. 'Si tu veux être libre et fort: travaille'. Het was het devies van mijn vader en ik heb het tot het mijne gemaakt. 
De levensfase waarin ik verkeer heeft deze karaktertrek versterkt. Blijven in Einstein had vermoedelijk betekend dat New York het eindpunt was geworden van mijn loopbaan. Die gedachte maakte me weemoedig. Ik voel me nog actief en vitaal genoeg om nog eenmaal een professionele berg te beklimmen, om nog één hoofdstuk aan mijn cv toe te voegen. Mijn komst naar Maastricht is dus in zekere zin een gesublimeerde manier om de onrust die het proces van veroudering bij mij oproept te hanteren.

Daar komt nog een belangrijke factor bij. Maastricht had aantrekkingskracht. De opdracht de drie vakgroepen binnen de psychiatrie - te weten Klinische Psychiatrie, Sociale Psychiatrie en Psychobiologie/Neuropsychologie - bijeen te brengen in een confederatie, trok mij aan. Ons vak is slecht gediend met een verbrokkeling volgens (pseudo)-filosofische gezichtspunten. Een tweede opdracht, die om samen met de leiding van de RIAGG/Vijverdal Combinatie bij te dragen tot de ontwikkeling van een 'Comprehensive Mental Health Delivery System' voor Maastricht en omstreken, was voor mij al even aantrekkelijk. Bundeling van psychiatrische programma's binnen één organisatorische structuur resulteert in optimalisering van zowel kwaliteit als continuiteit van zorg. In mijn afdeling in New York hebben we een dergelijk systeem opgezet en de voordelen ervan duidelijk kunnen demonstreren. De opdracht was aantrekkelijk, maar de professionele couleur locale was het ook: er zijn in de Maastrichtse Psychiatrie een aantal voortreffelijke programma's tot ontwikkeling gekomen.

Een laatste reden dat Maastricht ons aantrok, was het feit dat op één na al onze kinderen en kleinkinderen aan deze kant van de Atlantische Oceaan vertoeven. $\mathrm{Zij}$ zijn het beste dat wij bezitten en wij wilden graag dichter bij hen zijn. Dit sentiment werd sterker naarmate de tijd verstreek, de tijd begon op te raken. 
Maastricht is dus de vermoedelijke eindbestemming van een gevarieerde loopbaan die in Rotterdam begon en via Groningen en Utrecht naar New York voerde. De afwisseling heeft gelegen in het reisschema, niet zozeer in het programma. Ik ben een consistent mens, met bepaalde ideeën over zijn vak en de pogingen die te realiseren hebben de kwintessens van mijn leven gevormd. De kern van die denkbeelden is vroeg gevormd, al in mijn assistententijd. Weliswaar zijn ze in de loop van mijn leven verdiept, genuanceerd, gedifferentieerd, maar in wezen zijn ze weinig veranderd. Het zijn de kerncomponenten van mijn credo die ik nu, als hoofdbestanddeel van mijn les, aan $U$ wil voorleggen.

\subsection{Onderzoek om als vak te overleven}

Toen ik mijn loopbaan in de psychiatrie begon, nu precies 35 jaar geleden, werd er in ons vak praktisch geen empirisch onderzoek verricht. Een algemeen aanvaard en geoperationaliseerd systeem van diagnosen ontbrak. Methoden om gestoord gedrag te meten waren niet voorhanden. De basisvoorwaarden voor empirisch onderzoek ontbraken dus. De beschikbare kennis omtrent gestoord gedrag werd gevoed vanuit twee bronnen.

De eerste bron was een filosofische, een term die ik gebruik voor een reeks van theorieën, die niet zelden briljant en gedurfd waren, maar die in essentie berusten op casuïstiek, en waarvan de draagwijdte de oorspronkelijke observaties verre overschreed. Freud (dieptepsychologie), Jaspers(fenomenologie) en Binswanger (antropologie) waren van dit kennisdomein de onbetwiste bewindvoerders.

De tweede bron van psychiatrische kennis was terug te voeren op Kraepelin. Zij bestond uit de resultaten van nauwkeu- 
rige klinische observaties van bepaalde patiëntencohorten over lange tijdsperioden.

De meesters hadden fundamentele bijdragen geleverd, de navolgers raakten veelvuldig verstrikt in vruchteloze discussies over niet gesystematiseerde observaties, gedaan in sterk geselecteerde populaties en zonder dat duidelijk werd gemaakt welke diagnostische criteria waren gebruikt. Psychiaters van psychoanalytischen huize, diagnostiseerden op een strikt geïndividualiseerde, niet generaliseerbare manier. Hun belangstelling ging voornamelijk uit naar psychogenetische factoren, en voor symptomatologische aspecten van de diagnostiek hadden zij weinig belangstelling noch waardering. Psychopathologen, de spirituele nakomelingen van Kraepelin bewogen zich aan het andere uiterste van het spectrum. Zij waren geobsedeerd door symptomen, dit dikwijls ten koste van belangstelling voor hun (psycho)genese. Symptomen werden door hen vaak overgewaardeerd en voorzien van een pathognomonische valentie die ze in feite niet bezitten.

Diagnosen waren aldus niet gestandaardiseerd, niet gebaseerd op geoperationaliseerde criteria en in veel gevallen incompleet. Dit resulteerde in een spraakverwarring die aan de wetenschappelijke geloofwaardigheid van de psychiatrie afbreuk deed. Onze professie werd beschouwd als een praat-vak, dat weinig gaten vulde. Het ontbreken van research werd weggerationaliseerd, door de heterogeniteit van zowel de gezonde als de (geestes)zieke mens te accentueren, hetgeen valide generalisaties over gestoord gedrag onmogelijk zou maken.

Aan de ene kant voelde ik me op mijn gemak in dit literaire, filosofische klimaat. Het voorzag de studie van gestoord gedrag van een dimensie die in de rest van de geneeskunde ontbrak en die ik node had gemist. Aan de andere kant wekte het eindeloze gepraat, het onwrikbare geloof in woorden in plaats van in feiten, de overvloed aan theorieën, de bereidheid de ene hypothese 
op de andere te stapelen en deze bouwwerken als bastions te beschouwen in plaats van als kaartenhuizen, bij mij een intens gevoel van vervreemding op. Zo goed als voor andere medische disciplines, geldt voor de psychiatrie dat research een zaak is van levensbelang. Zonder dat kan het vak nooit tot wasdom komen, nooit salonfähig worden in medische kringen en zal het in toenemende mate terrein verliezen aan aanpalende disciplines die research wél serieus nemen, zoals neurologie en experimentele psychologie.

Ik heb een belangrijk deel van mijn leven gewijd aan het materialiseren van deze overtuiging.

\subsection{Het hersenen-en-gedrag mysterie}

Een opmerkelijke verbijzondering van de literaire en theoretiserende oriëntatie van de psychiatrie in die dagen was het flagrante gebrek aan belangstelling voor de hersenen. Jawel, we moesten destijds lichamelijk onderzoek doen, een elektroencefalogram maken en een lumbale punctie verrichten bij alle patiënten met ernstige psychopathologie. Dit alles geschiedde om wat werd genoemd 'organiciteit' aan te tonen of uit te sluiten. Die term verwees naar zware, morfologische hersenpathologie, gevolg van bijvoorbeeld een trauma, een bloeding of een tumor. De meeste psychiatrische ziektebeelden, zoals de depressies, de schizofrenieën, de angsttoestanden, de persoonlijkheidsstoornissen en de verslavingsziekten werden beschouwd als 'functioneel', ofschoon, zo leerden we, in sporadische gevallen organische hersenziekten zich als een 'functionele' aandoening konden vermommen. Deze 'functionele' psychiatrische ziektebeelden zouden ergens aan gene zijde van de hersenen ontstaan. $\mathrm{Zij}$ werden geacht het produkt te zijn van intrapsychische processen, die op de een of andere mysterieuze manier buiten de hersenen om het gedrag en beleven zouden beïnvloeden. 
Mainstream-psychiatrie leek de hersenen te hebben kortgesloten.

Het ontbrak mij aan begrip voor dit standpunt. Evenals in de rest van de geneeskunde, zo schreef ik in 1964 (Van Praag en Leijnse, 1964), moet men in de psychiatrie etiologie en pathogenese onderscheiden. Abnormaal gedrag vooronderstelt abnormaal functioneren van de hersenen en opheldering van deze processen zou de pathogenese van de gedragsstoornis definiëren. De disruptie van het cerebraal functioneren is op zijn beurt de resultante van een veelheid van factoren, biologisch, psychologisch of ecologisch van aard die te zamen de etiologie van de aandoening vertegenwoordigen. Zowel de pathogenese als de etiologie van de gedragsstoornis gaan de psychiater aan. Beide moeten bij de diagnose in aanmerking worden genomen, beide kunnen mogelijkheden tot therapeutische interventie bieden, beide vragen om wetenschappelijke exploratie. Biologische en psychosociale factoren verhouden zich complementair niet alternatief. Deze visie maakte me tot een overtuigd 'generalist' en behoedde me voor biologisch of psychosociaal extremisme (Van Praag, 1993).

Voor mijzelf was het hersenen-en-gedrag mysterie sinds mijn middelbare schooltijd het meest fascinerende aspect geweest van het menselijk bestaan. Hoe moet men zich - waarachtig in Gods naam - de transductie voorstellen van materiële hersenprocessen in een substantie die wij bijvoorbeeld ervaren als gevoelens, gedachten, emoties, strevingen, waarnemingen e.d. Men heeft werkelijk geen Bijbelse mirakels nodig om in wonderen te geloven.

Het toeval wilde dat ik mijn assistentschappen liep toen een reeks van innoverende psychofarmaca een ommekeer in de psychiatrie teweegbrachten. Lithiumzouten bleken profylactisch werkzaam bij uni- en bipolaire depressies. Neuroleptica sorteerden een therapeutisch effect bij psychosen. Stoffen werkzaam tegen depressies werden ontdekt, alsmede enkele typen 
van hoog selectieve anxiolytica. In deze ontdekkingen manifesteerde zich de betekenis van de hersenen als gedragsregulerend systeem op ondubbelzinnige wijze. Psychotrope stoffen werden het kristallisatiepunt van toetsbare hypothesen over de samenhang van het functioneren van de hersenen en het optreden van gestoord gedrag. Het effect van LSD op de centrale serotoninehuishouding genereerde de serotoninehypothese over het ontstaan van schizofrenie. De dopamine-blokkade teweeggebracht door neuroleptica, werd aanleiding tot de dopamine hypothese betreffende schizofrenie. Het vermogen van antidepressiva de beschikbaarheid van monoaminen in de hersenen te vergroten was het fundament van de veronderstelling dat bij bepaalde vormen van depressie de huishouding van deze neurotransmitters verstoord kan zijn.

Deze ontwikkelingen hadden een enorme invloed op me, intellectueel, ja zelfs emotioneel. Het conceptualiseren en bestuderen van dit type hypothese werd mijn voornaamste research-interesse; het verheffen van de biologische psychiatrie vanuit een aanvankelijke underdog-positie tot die van een psychiatrische hoofdstroming, een voorname doelstelling.

Onderzoek naar biologische determinanten van gestoord gedrag vooronderstelt, dat het object van studie nauwkeurig is gedefinieerd en vastgelegd. Biologisch onderzoek heb ik dan ook altijd hand in hand laten gaan met psychopathologisch onderzoek, dat is met onderzoek naar de diagnostiek van psychiatrische aandoeningen en naar methoden om ze op een adequate manier te meten. Samenwerking met experimentele klinische psychologen is voor voor mij dusdoende onontbeerlijk geweest. Ik wil deze uitspraak generaliseren. Voor de researchpsychiatrie is de experimentele klinische psychologie mijns inziens een onmisbare partner. Het is verheugend dat de Universiteit van Limburg deze koppeling zo nadrukkelijk heeft onderkend.

Geïnolveerd als ik vanaf $195^{8}$ was in hersenen- en gedragsonderzoek, werd ik weldra geoormerkt als een 'biologisch psy- 
chiater', een onderscheiding waar ik nooit erg gelukkig mee ben geweest. Ten eerste omdat de term zo vaak gebruikt wordt als de antithese van sociale en psychodynamische psychiatrie en de corresponderende psychologische interventies. Ik acht, zoals gezegd, die tegenstelling oneigenlijk. Mijn eerste openbare les gehouden in 1968, was getiteld: 'Het complementaire aspect in de relatie tussen biologische en psychodynamische psychiatrie' en ik heb nooit nagelaten te waarschuwen voor de potentiële gevaren van een overmatige 'biologisering' en objectivering van de psychiatrie: vergroving van de diagnostiek; preoccupatie met datgene wat objectief en onmiskenbaar waarneembaar is; verwaarlozing van de subjectieve componenten van het psychopathologisch spectrum; horizontalisme, dat is een systeem van diagnostiseren hoofdzakelijk gegrond in symptomen en losgemaakt van etiologische overwegingen, in het bijzonder van psychologische; oversimplificatie, dat is de classificatie van grofweg vergelijkbare, maar in feite heterogene syndromen in brede, globaliserende categorieën.

Een tweede reden waarom ik niet gelukkig was met de aanduiding 'biologisch psychiater' was, dat het desinteresse scheen te impliceren voor de geestelijke noden van de individuele patiënt. Niets is in mijn geval minder waar. Ik ben een algemeen clinicus gebleven met grote aandacht voor integrale patiëntenzorg. In New York kreeg ik de kans die belangstelling te concretiseren.

\subsection{Klinisch-academische toenadering}

De zogeheten academische psychiatrie rekent onderwijs, opleiding en onderzoek tot haar primaire verplichtingen. Patiëntenzorg wordt verricht om die taken te effectueren en niet als een verantwoordelijkheid sui juris. Ik heb dit dichotome denken altijd betreurd, omdat ik van mening ben dat de academische psychiatrie belangrijke bijdragen kan leveren tot optimalise- 
ring van de geestelijke gezondheidszorg en wel via het conceptualiseren, beproeven en evalueren van innoverende zorgmodellen. Anders uitgedrukt: ik beschouw het werken aan verbetering van de geestelijke gezondheidszorg qua kwaliteit, continuïteit, rendement en efficiëntie evenzeer als een academische taak als educatie en onderzoek. In Nederland had ik echter weinig gelegenheid om die belijdenis in daden om te zetten; in de Verenigde Staten des te meer.

In I98I werd ik uitgenodigd naar New York City te komen als hoogleraar/directeur van twee te fuseren afdelingen psychiatrie: die van het Albert Einstein College of Medicine en die van het Montefiore Medical Center. Deze afdelingen waren tot dan toe volledig onafhankelijk geweest, ieder met hun eigen Hoogleraar/Directeur, assistentenprogramma's, staf, budget e.d. Elk van die afdelingen was los geaffilieerd met een aantal psychiatrische instituten en programma's in the Borough of the Bronx.

Deze constellatie leek mij in principe de mogelijkheid te bieden om de voornaamste psychiatrische programma's in de Bronx bijeen te brengen binnen een geïntegreerd verband. Deze mogelijkheid werd door mij en mijn medewerkers geëffectueerd. De academische afdeling Psychiatrie van Einstein/ Montefiore groeide uit tot een gemenebest bestaande uit: vijf afdelingen psychiatrie in algemene ziekenhuizen, een algemeen psychiatrisch ziekenhuis, een ziekenhuis voor kinder-en jeugdpsychiatrie, twee Community Mental Health Centers (vergelijkbaar met onze RIAGG's) en een groot gedecentraliseerd verslavingsprogramma met zowel klinische als ambulante componenten. Te zamen zijn deze instellingen verantwoordelijk voor de geestelijke gezondheidszorg in het grootste deel van de Bronx, een stadsdeel met I, 3 miljoen inwoners.

Dit gemenebest wordt geleid door een bestuur dat wekelijks bijeenkwam onder mijn voorzitterschap. Het bestaat uit de Hoofden van de tien participerende afdelingen, de divisiehoofden (elk verantwoordelijk voor een bepaald klinisch domein in 
alle tien 'deelstaten', zoals kinder- en jeugdpsychiatrie, neuropsychiatrie, psychogeriatrie, liaison-consultatie psychiatrie, klinische psychologie e.a.), Hoofd Onderwijs en Opleiding, vertegenwoordigers van de laboratorium en klinische researchprogramma's en de 'senior chief resident'. In het bestuur van het gemenebest hebben dus - om het Nederlandse jargon te gebruiken - zowel vakgroep- als niet-vakgroepleden zitting; academici en clinici (een schijntegenstelling, die in een academische setting irrelevant zou moeten zijn); onderzoekers en practici. Dienovereenkomstig vermeldde de agenda van de bestuursvergaderingen, behalve punten betreffend onderwijs, opleiding en de logistieke aspecten van onderzoek, ook en vaak overwegend onderwerpen uit de patiëntenzorg. Enkele voorbeelden: hoe kan met de beschikbare menskracht en middelen het hoogste therapeutische rendement worden verkregen; welke nieuwe programma's behoeft de regio het meest en waar moeten die worden gelokaliseerd; hoe kan de verschuiving van intramurale naar extramurale patiëntenzorg worden bevorderd; zijn de behandelingsprogramma's up to date; is revalidatie voldoende geïntegreerd in het behandelingsbeleid; is continuïteit van zorg genoegzaam gegarandeerd, e.d.

Het klinische en het academische domein werden in en door het bestuur vanuit een centraal uitkijkpunt bezien. Anders gezegd: optimalisering van de geestelijke gezondheidszorg kreeg academische status. De grenzen tussen het academische en het klinische domein waren open; grensverkeer werd aangemoedigd; grensconflicten en interinstitutioneel egocentrisme ontmoedigd.

Het was niet alleen de behoefte om de geestelijke gezondheidszorg te optimaliseren die de deelnemende instellingen bewoog tot deze vorm van intensieve samenwerking. Er waren ook andere bekrachtigende factoren, zoals het betrokken raken bij de in engere zin academische taken als onderwijs en opleiding en de mogelijkheden deel te nemen aan wetenschappelijk onderzoek. Bovendien vergemakkelijkt de universitaire status 
het aantrekken van staf. Voor de Universiteit ligt de charme van haar Afdeling Psychiatrie, in het feit dat deze werkelijk een microkosmos vertegenwoordigt van alles wat de hedendaagse psychiatrie, diagnostisch en therapeutisch, te bieden heeft en dat die Afdeling zo overtuigend demonstreert dat academia kan worden bedreven met beide voeten op de grond van de dagelijkse praktijk.

In het samenwerkingsverband van de deelnemende instituten werd nadrukkelijk een federale structuur nagestreefd. De Verenigde Staten waren mijn model, niet (het voormalige) Joegoslavië. Ik heb niet gepoogd uit de 'deelstaten' een (pseudo)eenheid te creëren met een uit zijn krachten gegroeide centrale autoriteit. Een gemenebest was mijn doel, waarin elk lid een belangrijk deel van zijn autonomie en identiteit behield en de bevoegdheid van het centrale bestuur zich beperkte tot planning, coördinatie en vooral ook enthousiasmering en verspreiding van de boodschap dat men er beter op kan worden door iets in te leveren. Het centrale bestuur is daarmee geen bron van vrees en achterdocht geworden. De beperkingen die het zichzelf had opgelegd waren omgekeerd evenredig met zijn invloed.

De grootte van het bestuur met zijn circa 25 leden, deed geen afbreuk aan zijn daadkracht en slagvaardigheid en waarborgde dat genomen beslissingen een breed draagvlak hadden. Tussen het Afdelingshoofd, tevens voorzitter van het Afdelingsbestuur, en de Bestuursleden waren geen andere centrale managers aangesteld. De organisatielijnen waren dus uiterst kort. Deze structuur, alsmede de brede en voor de afdeling representatieve samenstelling van het Bestuur, waren de voornaamste redenen dat in de geestelijke gezondheidszorg van de Bronx in korte tijd veel ten goede kon veranderen.

Natuurlijk zijn bestuursmodellen die effectief zijn in een bepaalde regio, niet zonder meer overdraagbaar naar een andere demografische, geografische en politieke constellatie. Toch ben ik bereid te concluderen, dat de grondgedachte van het geschetste model universele waarde heeft wanneer optimali- 
sering van kwaliteit, continuïteit en rendement van de geestelijke gezondheidszorg wordt nagestreefd: alle instituten en organisaties werkzaam op dit terrein in een bepaalde regio worden in confederatief verband bijeengebracht, met een bestuur waaraan de afzonderlijke leden bepaalde (nader te specificeren) bevoegdheden hebben gedelegeerd.

In Maastricht hebben de RIAGG en het Psychomedisch Streekcentrum Vijverdal recentelijk besloten tot een fusie. Dit lijkt mij een uitnemende beslissing, waarbij ik slechts één kanttekening plaats, maar wel een belangrijke. Terwille van een geintegreerde geestelijke gezondheidszorg in de regio dient de Afdeling Psychiatrie van het Academisch Ziekenhuis Maastricht in dit samenwerkingsverband te worden opgenomen. Het verheugt mij dat deze visie principieel door alle partijen wordt gedeeld. Zo zal het Psychiatrisch Gemenebest dat in Maastricht vorm gaat krijgen een voorbeeld kunnen vormen voor de natie.

\subsection{Filosofische detente}

Onderlinge verkettering was in de psychiatrie jarenlang de regel. Voorbeelden hiervan zijn er te over. Psychoanalytici bezaten vele decennia een therapeutisch monopolie. Na de jaren vijftig werden andere psychotherapeutische methoden ontwikkeld, zoals cognitieve en gedragstherapie en nieuwe therapeutische strategieën geïntroduceerd, bijvoorbeeld groeps- en gezinstherapie. Psychoanalyse bleef echter lang de goudstandaard van de psychologische interventies en analytici keken aanvankelijk onverholen op deze nieuwlichterijen neer. Biologische psychiatrie en psychofarmacologie werden door vakgenoten van allerlei pluimage, geruime tijd met dédain bezien. Psychofarmaca zijn 'slechts' symptoombestrijders, was een geijkte opmerking, suggererend dat alleen met psychotherapie de kern, het 'wezen' van een psychiatrische aandoening kan worden geraakt (standpunten die, zoals ik in paragraaf 2.2 uit- 
eenzette, geen steek houden wanneer men etiologie en pathogenese van een psychiatrische aandoening van elkaar onderscheidt). Gestandaardiseerde methoden van gedragsbeoordeling zouden slechts een karikatuur van een psychiatrische diagnose opleveren en bij de meeste psychiatrische ziekten werd het zoeken naar biologische determinanten praktisch gelijkgesteld met het najagen van hersenschimmen. Een bekend hoogleraar in de psychiatrie voegde mij nog midden jaren zeventig in alle ernst toe, dat ik bezig was de psychiatrie te vernietigen. Een uitspraak typerend voor de combinatie van angst en onzekerheid waarmee de opkomst van het empirische denken in de psychiatrie werd ontvangen.

Aan de andere kant kon men in kringen van biologisch geïnteresseerde psychiaters de mening horen dat 'praat-therapie' niet gegrond is op enige wetenschappelijke basis en dus niet veel meer is dan een gedistingeerde vorm van kwakzalverij, op zijn best aanvaardbaar als interim-maatregel totdat de geëigende psychofarmaca ontwikkeld waren.

Werkers in de sociale psychiatrie hebben in een bepaalde ontwikkelingsfase van dit deelgebied de sociale visie op abnormaal gedrag alleen zaligmakend verklaard. Aan het zgn. 'medische model' werden satanische kwaliteiten toegedacht. Toepassing ervan werd voor de patiënt schadelijk geacht. In de meest extreme variant van deze visie - de antipsychiatrie - werd het begrip psychiatrische ziekte tot een fictie. Het dekte niet veel meer dan mystificaties van een verdorven maatschappij, die haar ogen sluit voor haar eigen doorslaggevende rol bij het ontstaan van geestesziekten.

Als laatste voorbeeld van een psychiatrische godsdiensttwist noem ik de geringe achting die pogingen genoten om aan psychiatrische patiënten nieuwe vaardigheden te leren. Revalidatie, social skill training, psycho-educatie, om enkele van deze methoden te noemen, behoren in feite tot de meest heilzame psychologische interventies die wij aan de verschillende groepen van chronische psychiatrische patiënten hebben te bieden. 
Toch zijn dit methoden waar een rechtgeaarde psychotherapeut zich ongaarne mee bezighoudt en als hij het doet meent dat hij op dat moment geen psychotherapie bedrijft. Het zouden methoden zijn voor 'lager gekwalificeerd personeel'.

Ik heb met dit en dergelijk getheologiseer nooit enige affiniteit gevoeld - sterker nog, ik vond het ronduit destructief. Het deed grote afbreuk aan de kwaliteit van de patiëntenzorg. Met deze of gene quasi-theologie werd monotherapie gerechtvaardigd. Zo was psychotherapie geruime tijd onverenigbaar met psychofarmaca. Anderen verwaarloosden psychotherapie wanneer doelmatige farmaca voorhanden waren. Vele psychotherapeuten pasten slechts één vorm van psychotherapie toe; die waarin zij 'geloofden'. De stelling dat je ook in de psychotherapie beter met twee handen vecht dan met één hand op de rug, werd verworpen.

Het toppunt van onethische zelfbegoocheling was de dichotome patiëntenverdeling die in de psychiatrie in mijn assistententijd en nog lang daarna aanvaardbaar werd geacht. Er werden 'goede' en 'slechte' patiënten onderscheiden. 'Goed' stond voor jong, intelligent, introspectief; kwaliteiten die iemand geschikt zouden maken voor inzichtgevende psychotherapie, tenminste als men uit vrije wil voor deze behandeling koos. De kwalificatie 'slecht' gold voor patiënten die wat ouder waren, qua intelligentie onder de gestelde maat bleven, weinig geneigd waren tot zelfreflectie en terughoudend reageerden op de mogelijkheid van inzichtgevende therapie.

Deze instelling heeft desastreuze gevolgen gehad. Grote groepen patiënten zijn lange tijd therapeutisch verwaarloosd, waaronder de chronische schizofrenen, de verslaafden en de organisch gestoorde patiënten. Op de psychiaters die het aandurfden de Zeitgeist te trotseren en besloten hun leven te wijden aan de therapeutisch onderbedeelden werd vaak neergezien door vakbroeders met psychotherapeutische praktijken. Psychiatrische ziekenhuizen waren in die dagen vaak niet veel meer dan instituten waar geestelijk gestoorden werden opgeborgen. 
De antipsychiatrische revolutie in de jaren zeventig schudde een discipline wakker die verstrikt was geraakt in doctrines die onethisch gedrag moesten rechtvaardigen. Het ontwaken was ruw, is vergezeld gegaan van schadelijke nevenwerkingen, maar was bitter nodig.

Zo maakte ik in de eerste fase van mijn loopbaan kennis met een zelfingenomen discipline, die goeddeels in zichzelf opging en te weinig in haar clientèle. Ik heb oprecht getracht de verleiding van exclusivisme te weerstaan. Wat ik steeds heb nagestreefd is een pragmatisch-eclectische psychiatrie, gericht op uitbreiding van haar empirische databank, wars van diagnostische en therapeutische bigotterie en gebruikmakend van alle behandelingsmethoden waarvan effectiviteit aannemelijk is gemaakt. Gelukkig is die opvatting sinds de jaren tachtig steeds meer veld gaan winnen.

\subsection{Blondering van het zwarte schaap}

Ten tijde van mijn assistentschappen genoot ons vak in de medische gemeenschap geen hoog aanzien. Het werd gezien als een specialisme gebaseerd op woorden, meer dan op feiten; geschoold in theorievorming maar niet in empirisch onderzoek; sprekend in een voor medici slecht toegankelijke sprake; onbetrouwbaar in de diagnostiek en in therapeutisch opzicht goeddeels impotent. Het beeld was karikaturaal overtrokken, maar in wezen niet onjuist. Een dergelijke stand van zaken is voor disciplines in een pre-wetenschappelijke fase van ontwikkeling niet ongewoon. Het zorgelijke in ons vak was echter, dat de prewetenschappelijkheid van de situatie niet werd erkend en de impressionistische, casuïstische benadering voor wetenschappelijk werd gehouden.

Mij heeft die laatdunkende en meesmuilende manier waarmee zo vaak over de psychiatrie werd gesproken, verdroten en geprikkeld. Ik kon er mij niet bij neerleggen en heb, ik mag wel 
zeggen hartstochtelijk, getracht de beeldvorming te veranderen. Nauwere aansluiting van de psychiatrie bij de rest van de geneeskunde kan, zo redeneerde ik destijds, langs verschillende wegen worden bereikt en die marsroutes acht ik nog steeds doelmatig.

Consultatieve psychiatrie, onze vooruitgeschoven post in de geneeskunde, zou ontwikkeld moeten worden als een volwaardige subdiscipline. Die uitspraak is nog onverkort van kracht. Consultatieve psychiatrie is in ons land, zeker in vergelijking met de Verenigde Staten, onvoldoende tot ontwikkeling gekomen. Voorts zouden standaardisering en operationalisering van de psychiatrische diagnostiek en de ontwikkeling van meetmethoden voor gestoord menselijk gedrag de hoogste prioriteit moeten krijgen, zijnde basisvoorwaarden voor wetenschappelijke ontwikkeling. Er is in deze in de loop der jaren grote vooruitgang geboekt maar we bevinden ons wat deze desiderata betreft nog steeds in een beginfase. Om de psychiatrie in medische kringen 'salonfähig' te maken, zouden behandelingsmethoden systematisch geëvalueerd moeten worden en onderling moeten worden vergeleken op hun therapeutisch rendement. In de farmacopsychiatrie is dit desideratum verwerkelijkt. De psychiatrie heeft bij de ontwikkeling van de klinische farmacologie zelfs een voortrekkersrol gespeeld. Bij sommige psychologische interventies, zoals gedrags- en cognitieve therapie is evaluatie nu de regel, maar dat geldt zeker niet voor alle vormen van psychotherapie. Met name psychodynamisch gefundeerde, individuele en niet-individuele vormen van psychotherapie hebben in deze nog een achterstand in te lopen.

De ontwikkeling van de biologische psychiatrie, tenslotte, zou zowel de vocabulaire als de ambiance verschaffen voor een psychiatrisch-medische toenadering en zou alleen al daarom moeten worden toegejuicht. In diezelfde gedachtengang zag ik het huwelijk tussen psychiatrie en neurologie, nog intact toen ik met dit vak begon, als een essentiële schakel in het proces van 'versalonfähigung' van de psychiatrie. In de jaren zeventig ech- 
ter besloten de gouverneurs van beide vakorganisaties het huwelijk te ontbinden en de training in psychiatrie en neurologie praktisch gesproken te ontkoppelen. Dit besluit werd genomen, net toen de studie van de hersenen voor de psychiatrie relevant begon te worden; toen de psychofarmacologie een bloeitijd tegemoet scheen te gaan; toen de neuropsychiatrische interface expandeerde. Het besluit van onze ouderlingen bæs schouwde ik als een dusdanige stupiditeit, dat alles in het werk zou moeten worden gesteld om het effect van deze beslissing ongedaan te maken en psychiaters in training te bevrijden van angst voor het lichaam in het algemeen en voor de hersenen in het bijzonder en van gevoelens van vervreemding wanneer zij in medische kringen verkeren.

Naast scholing in systematische, multidimensionele diagnostiek en training in biologische en de voornaamste psychologische behandelingsmethoden, zie ik dit als een centrale doelstelling van de opleiding tot psychiater.

\subsection{Onderwijs in de psychiatrie: op zoek naar een sokkel}

Zoals gezegd, heb ik legitimisering van de psychiatrie binnen de medische gemeenschap bewust en actief nagestreefd. Ik liet één strategie die hiertoe kan bijdragen buiten beschouwing. Ik vind deze essentieel en wil haar derhalve apart bespreken. Ik doel op het onderwijs aan medische studenten als middel om de beeldvorming van ons vak te verbeteren.

De opleiding van artsen bestaat uit drie modules, te weten basiswetenschappen, klinische wetenschappen en klinische praktijk. Aan sommige universiteiten worden ze opeenvolgend onderwezen, aan andere gelijktijdig. De basisvakken zijn altijd die geweest, die de grondslag vormen voor de interne geneeskunde en de chirurgie. Om het lichamelijk dysfunctioneren van de mens te verhelderen, zo wordt terecht geredeneerd, is inzicht nodig in de grondprocessen die het lichamelijke functioneren 
van de mens sturen. Ten tijde van mijn medische studie ontbrak een pathopsychologisch equivalent. De grondprocessen die het psychische leven sturen en kennis waarvan vereist is om te begrijpen hoe ontsporingen binnen het psychische apparaat kunnen ontstaan, werden niet als zodanig onderwezen. Deze situatie is in de loop der jaren wel wat verbeterd, maar van een goed herkenbaar psychiatrisch basiscurriculum is nog steeds geen sprake. Ik vind dit een ernstige tekortkoming. De medische student krijgt zo licht de indruk, dat wetenschappen die fundamenteel zijn voor de psychiatrie ofwel niet bestaan ofwel dezelfde zijn als die de interne geneeskunde en de chirurgie schragen. Beide veronderstellingen zijn uiteraard onjuist.

Een basiscurriculum voor de psychiatrie zou uit drie gedeelten moeten bestaan. Het eerste blok is gericht op de relatie tussen hersenen en gedrag en laat zich ongedwongen inpassen in het gangbare basispakket. Hierin worden onder meer de principes van zenuwgeleiding en neurotransmissie besproken, hun rol in de gedragsregulatie van mens en dier onder normale en ziekelijke condities en de beinvloedbaarheid van de desbetreffende neuronale systemen door farmacologische en psychologische interventies.

In het tweede gedeelte komen de psychologische wetenschappen aan de orde. In deze module wordt onder meer gesproken over psychologische functies, zoals: informatieverwerking, geheugen, cognitie, agressie-, angst- en stemmingsregulatie, emotionaliteit en vele andere. Hun onderlinge interactie wordt belicht, de beschikbare methoden om ze te mèten en de mogelijkheden om hun doelmatigheid te vergroten in geval van dysfunctie. Psychiatrische ziektebeelden worden vervolgens ontleed in de samenstellende bestanddelen, zijnde psychologische dysfuncties en deze worden zo mogelijk gerelateerd aan neuronale systemen die die eindverantwoordelijkheid dragen voor hun normale of abnormale verloop. Voorts wordt de vraag besproken of er therapeutische maatregelen bestaan om in geval van psychiatrische ziekte, de functionele homeostasis te 
normaliseren of te verbeteren. Deze wijze van analyseren van het psychische apparaat levert het mentale equivalent op van de anatomie en fysiologie die traditioneel aan a.s. artsen worden onderwezen. Een ander thema dat aan de orde moet komen is de psychologische ontwikkelingsgang van de mens en de oorzaken van scheefgroei.

Het derde part van een psychiatrisch basiscurriculum zal aandacht besteden aan de sociale c.q. ecologische determinanten van menselijk gedrag. Welke invloeden uit het milieu dragen bij tot het ontsporen van menselijk gedrag? Hoe kan de grens worden getrokken tussen de gevolgen van maatschappelijke nood en psychiatrische ziekte? Hoe verhouden zich erfelijke en maatschappelijke invloeden bij het ontstaan van bepaalde psychiatrische syndromen? In dit blok komen dus thema's aan de orde uit de medische sociologie, psychiatrische epidemiologie, populatiegenetica, voedingsleer e.d.

Een psychiatrisch basiscurriculum voor medische studenten (dat hier uiteraard slechts als zeer ruwe schets is weergegeven) kan niet zonder meer aan het bestaande studiepakket worden toegevoegd; dat barst nu al bijna uit zijn voegen. De realisering ervan zou een totale revisie van het gehele curriculum noodzakelijk maken, maar dit zou gerechtvaardigd zijn. Zonder af te willen dingen op het belang van de interne geneeskunde en de chirurgische disciplines, betreur ik in hoge mate de onderrepresentatie van de psychiatrische basiswetenschappen en van de psychiatrie als klinische discipline in de medische studie, terwijl de meeste artsen toch vrijwel dagelijks geconfronteerd zullen gaan worden met stoornissen in de geestelijke gezondheid en met psychosomatische interacties. De psychiatrie is een 'groot vak'; in termen van aantallen patiënten, mate van invalidering die psychiatrische ziekten teweegbrengen en inductie van individueel lijden de evenknie van de interne geneeskunde en chirurgie.

De afwezigheid van een basiscurriculum voor de psychiatrie leidt ertoe, dat de medische student slecht voorbereid het 
domein van de psychiatrie als klinische wetenschap en dus ook als praktische discipline binnenstapt. Van dit vacuüm gaat de suggestie uit, dat de psychiatrie geen wetenschappelijk fundament bezit; het continueert het stereotiep dat het een onwetenschappelijk vak is, een overwegend verbale propositie zonder empirische basis, een standbeeld zonder een sokkel. Het maakt de wetenschappelijk geïnteresseerde student kopschuw voor ons vak en doet ernstig onrecht aan de indrukwekkende vooruitgang van de psychiatrie en verwante disciplines in de afgelopen decennia.

In mijn eigen onderwijs heb ik altijd getracht aan deze opvatting concreet gestalte te geven. Het is mij niet gelukt de medische faculteiten waar ik lid van ben geweest aan mijn zijde te krijgen. Toch blijf ik in de juistheid van mijn standpunt geloven en meen dat de beroepsverenigingen van psychiaters dit onderwerp op hun agenda zouden moeten plaatsen en concrete voorstellen uitwerken voor de organisaties met eindverantwoordelijkheid voor het medische onderwijs. Wanneer wij psychiaters dat niet doen, wie dan wel?

\section{De laatste berg}

Uit mijn credo moge duidelijk zijn hoe ik me voorstel de Maastrichtse berg te beklimmen. Ik zal trachten partijen bijeen te brengen en tot intensievere samenwerking te bewegen; partijen van clinici en academici; partijen van laboratorium- en klinische onderzoekers; partijen van medisch en niet-medisch opgeleide werkers in de geestelijke gezondheidszorg; partijen die verbonden zijn aan het Academische Ziekenhuis en partijen die werken in de twee reeds gefuseerde Zusterinstituten. Partijen die te zamen het fundament zullen moeten vormen voor de nieuwe Psychiatrische Universiteitskliniek die voor Maastricht is gepland; partijen die met elkaar een multidimensioneel en 
geïntegreerd psychiatrisch zorgsysteem zullen moeten opbouwen voor Maastricht en omstreken. Ik hoop bij te dragen tot verdere bloei van het wetenschappelijke onderzoek in onze Vakgroep en tot grotere coördinatie hiervan. Het ligt, tenslotte, in mijn bedoeling het onderricht in de psychiatrie kritisch te bezien en de vraag te stellen of het in voldoende mate de 'state of the art'van de jaren negentig weerspiegelt.

Een ambitieus programma dus voor een vijftal jaren. In het eerste gesprek dat ik met de psychiatrische assistenten had, vroeg een van hen of ik me als een soort tussenpaus beschouwde. Ik antwoordde: neen, als u hiermee een kleurloze tussenfiguur bedoelt; ja, als u suggereert dat mij voor mijn taak weinig tijd gegeven is. Medewerkers van het Academisch Psychiatrisch Centrum, veel hangt derhalve van u af! Om een succesvol tussenpaus te zijn, bent u onontbeerlijk. Zonder uw actieve en loyale medewerking zal het me niet lukken. Ik ben me daar ten volle van bewust en spreek op deze plaats nogmaals de hoop uit, dat we in de komende jaren in eendracht zullen optrekken. Als mijn eerste Maastrichtse maanden representatief zouden zijn voor mijn gehele ambtsperiode, twijfel ik er niet aan dat we de top zullen bereiken. Ik van mijn kant zal mijn best blijven doen om uw vertrouwen te versterken en uw medewerking te vergemakkelijken.

Moge er op onze gemeenschappelijke inspanningen zegen rusten!

\section{$4 \quad$ Dank}

Aan het einde gekomen van mijn oratie, wil ik tenslotte de Raad van Bestuur van het Academisch Ziekenhuis Maastricht, en met name haar voorzitter; de Decaan en Directeur van de Faculteit der Geneeskunde; het College van Bestuur en met name haar voorzitter en de Rector van deze Universiteit dan- 
ken voor de prettige en produktieve contacten die ik in de periode voorafgaande aan mijn komst naar Maastricht met hen heb gehad. Moge deze relatie voortduren! Ik heb óók uw steun en medewerking nodig om mijn taak naar behoren te kunnen vervullen.

Tenslotte en boven alles wil ik dank betuigen aan mijn vrouw. Ik dank je, Nelleke, voor je bereidheid je echtgenoot, die alsmaar op pad moet zijn en niet tot rust schijnt te kunnen komen, in zijn Maastrichtse plannen te steunen. Je hebt in New York veel achtergelaten en ik besef dat je jouw belangen ondergeschikt hebt gemaakt aan de mijne.

Ik dank je voor wat je nu al zo'n kleine veertig jaar voor me bent geweest: de spil van mijn leven. Zonder jou zou de Vliegende Hollander vleugellam zijn en de Wandelende Jood een geketende. Zonder jou zou ik het beklimmen van deze laatste berg niet hebben aangedurfd. Ik dank de Hemel dat je naast me staat.

Ik heb gezegd. 


\section{LITERATUUR}

H.M. van Praag \& B. Leijnse. Die Bedeutung der Psychopharmakologic für die klinische Psychiatrie. Systematik als notwendiger Ausgangspunkt. Nervenarzt 1964; 34:530-537.

H.M. van Praag. Het complementaire aspect in de relatie tussen biologische en psychodynamische psychiatrie. Openbare Les, Van Gorcum, Assen, 1968.

H.M. van Praag. Make Believes in Psychiatry or The Perils of Progress. Brunner Mazel, New York, 1993. 